\title{
STUDI EKSPERIMEN: PENGARUH STRATEGI PEMBELAJARAN DAN MINAT BELAJAR SISWA TERHADAP HASIL BELAJAR FIQIH
}

\author{
Lisa'diyah Ma'rifataini
}

\begin{abstract}
ThisstudyaimsatexaminingtheeffectofCooperativelearningstrategiesandcompetitivelearning strategies to improve student learning outcomes in Figh subject associated with student interest. The research method used is experimental method with a $2 \times 2$ factorial design, the population target of which is the entire students of State Islamic Junior High Schools (MTsN) in East Jakarta. The findings of this study are: first, as a whole, the Fiqh learning outcomes of students treated using the Cooperative learning were higher than those treated using the competitive learning. Second, for students who have a high interest in learning, the Figh learning outcomes of students treated using the Cooperative learning were higher than those treated using the competitive learning. Third, for students who have low interest in learning, the Fiqh learning outcomes of students treated using the competitive learning were higher than those treated using the Cooperative learning. Fourth, There was an interaction effect between the Cooperativelearning and the competitivelearningand students'interestinlearning (high and low) to the Figh learning outcomes of students.
\end{abstract}

Keywords: Experimental Method, Learning Strategies, Cooperative, Competitive, Interest in Learning

\section{Abstraksi}

Studi ini bertujuan untuk menguji pengaruh strategi pembelajaran kooperatif dan strategi pembelajaran kompetitif dalam meningkatkan hasil belajar siswa pada mata pelajaran Fiqh dikaitkan dengan minat belajar siswa. Metode penelitian yang dipakai adalah Eksperimen dengan desain faktorial 2x2, populasi targetnya adalah seluruh siswa MTs Negeri se-Jakarta Timur. Temuan dari hasil studi ini ditemukan: pertama, Secara keseluruhan, hasil belajar Fiqih siswa yang diberi perlakuan Pembelajaran kooperatif lebih tinggi dari hasil belajar Fiqih siswa yang diberi pembelajaran kompetitif. Kedua, siswa yang memiliki minat belajar tinggi, hasil belajar Fiqih bagi siswa yang diberi perlakuan Pembelajaran kooperatif lebih tinggi dari siswa yang diberi pembelajaran kompetitif. Ketiga, siswa yang memilikiminatbelajar rendah, hasil belajar Fiqih bagisiswayang diberipembelajaran kompetitif, lebih tinggi dari yang diberi perlakuan Pembelajaran kooperatif. Keempat, Terdapat pengaruh interaksi antara Pembelajaran kooperatif dan kompetitiflearning dengan minat belajar (tinggi dan rendah) terhadap hasil belajar Fiqih siswa.

Kata kunci: eksperimen, strategi pembelajaran, kooperatif, kompetitif, minat belajar

Naskah diterima, 12 Januari 2012. Revisi pertama, 17 Februari 2012, revisi kedua 3 Maret 2012, revisi ketiga 7 April 2012 


\section{PENDAHULUAN}

\section{Latar Belakang Masalah}

Undang-Undang Republik Indonesia No. 20 tahun 2003 tentang sistem pendidikan nasional pasal 3 disebutkan bahwa pendidikan nasional berfungsi mengembangkan kemampuan dan membentuk watak serta peradaban bangsa yang bermartabat dalam rangka mencerdaskan kehidupan bangsa, bertujuan untuk berkembangnya potensi peserta didik agar menjadi manusia yang beriman dan bertaqwa kepada Tuhan Yang Maha Esa, berakhlak mulia, sehat, berilmu, cakap, kreatif, mandiri dan menjadi warga negara yang demokratis serta bertanggung jawab. ${ }^{1}$

Pemerintah Indonesia telah banyak melakukan upaya meningkatkan mutu pendidikan. Salah satu perubahan mendasar dalam bidang pendidikan Indonesia adalah disahkannya Undang-undang (UU) Pendidikan Nasional Nomor 20 tahun / Tanggal 8 Juli 2003 yaitu: (1) tentang sistem pengelolaan pendidikan, (2) sistem pembangunan pendidikan yang mesti dikendalikan dengan visi dan misi serta strategi yang jelas. Salah satu folosofi pembangunan pendidikan di masa depan adalah, pendidikan diselenggarakan sebagai suatu proses pembudayaan dan pemberdayaan peserta didik yang berlangsung sepanjang hayat, pendidikan diselenggarakan dengan memberikan keteladanan, membangun kemauan, mengembangkan minat peserta didik dalam proses pembelajaran. Di sisi lain peningkatan mutu pendidikan juga diimplementasikan dengan meningkatkan anggaran pendidikan (meskipun belum mencukupi), menambah jumlah sarana dan prasarana pendidikan, pengembangan kurikulum, meningkatkan kuantitas maupun kualitas guru, mengembangkan sistem manajemen dan pelayanan sekolah.

1 Undang-Undang Republik Indonesia Nomor 20 Tahun. 2003 tentang Sistem Pendidikan Nasional.
Pada kenyataannya upaya yang dilakukan pemerintah dalam membenahi sistem pendidikan di Indonesia masih dihadapkan kepada banyak persoalan. Salah satu di antara persoalan itu adalah rendahnya mutu lulusan pendidikan di Indonesia, baik di tingkat Madrasah Tsanawiyah (MI), Madrasah Tsanawiyah (MTs), Madrasah Aliyah (MA) bahkan Perguruan Tinggi (PT). Hal ini ditandai oleh rendahnya hasil belajar yang diperoleh peserta didik ketika mereka menyelesaikan serangkaian kegiatan proses belajar.

Salah satu mata pelajaran yang perlu mendapat perhatian untuk tujuan tersebut di atas adalah kemampuan dalam menguasai mata pelajaran Fiqh. Mata pelajaran Fiqh merupakan mata pelajaran yang penting dan bermanfaat terutama dalam mengimbangi perkembangan ilmu pengetahuan umum. Disamping itu ilmu Fiqh wajib dipelajari sebagai satu ilmu untuk melakukan peribadatan dalam kehidupan sehari-hari.

Mata pelajarn Fiqih wajib dipelajari namun pada kenyataannya hasil belajar siswa dalam mata pelajaran Fiqih rendah. ${ }^{2}$ Permasalahan rendahnya hasil belajar siswa, khususnya dalam mata pelajaran Fiqh ini perlu mendapat perhatian yang lebih serius. Artinya diperlukan usaha-usaha yang dapat meningkatkan prestasi belajar siswa khususnya dalam mata pelajaran Figh terutama melalui penelitian yang mendalam tentang faktor penyebab rendahnya hasil belajar Figh di tingkat Madrasah Tsanawiyah.

Selanjutnya, dalam konteks UU No. 20 Tahun 2003 tentang Sisdiknas, madrasah menghadapi tantangan yang sangat besar. Sebagai sub-sistem pendidikan nasional yang termasuk ke dalam jenis pendidikan umum, madrasah dituntut untuk melaksanakan PP. Nomor 19 Tahun 2005 tentang Standar Nasional Pendidikan

2 Data nilai Fiqih siswa MTs tahun 2008 di wilayah Jakarta Timur. 
(SNP) sebagai dasar dalam perencanaan, pelaksanaan dan pengawasan pendidikan (pasal 3), dengan tujuan untuk menjamin mutu pendidikan nasional dalam rangka mencerdaskan kehidupan bangsa dan membentuk watak serta peradaban bangsa yang bermartabat (pasal 4).

Menurut UU No. 20/2003, jenis pendidikan umum jenjang pendidikan dasar adalah berbentuk SD dan MI atau bentuk lain yang sederajat, serta SMP dan MTs atau bentuk lain yang sederajat, sedangkan pendidikan menengah berbentuk SMA, MA, SMK dan MAK, atau bentuk lain yang sederajat (Bab VI pasal 17 dan 18)3.

Pernyataan pada pasal 17 dan 18 ini menunjukkan bahwa posisi madrasah adalah sama atau sederajat dengan sekolah, yaitu termasuk ke dalam jenis pendidikan umum, berbeda dengan undang-undang sebelumnya yang menyatakan bahwa madrasah adalah sekolah umum berciri khas Islam. Kesamaan posisi ini bagi madrasah diduga menyisahkan sejumlah implikasi yang sangat serius, khususnya berkaitan dengan capaian idealisme yang ingin diraih oleh madrasah, yang dibangun atas dasar visi dan misi madrasah sebagai lembaga pendidikan Islam.

Dengan adanya perubahan tersebut juga diduga mempunyai dampak terhadap minat belajar siswa pada mata pelajaran tertentu. Dengan adanya kebijakan terhadap pemilihan mata pelajaran umum untuk ujian akhir nasional dapat mengurangi minat belajar siswa terhadap minat mata pelajaran yang bernuansa Islam seperti mata pelajaran Fiqh. Untuk mengatasi permasalahan ini maka perlu dilakukan dilakukan penelitian untuk upaya meningkatkan minat belajar siswa terhadap belajar mata pelajaran Fiqh termasuk melalui pembelajaran Cooperative dan pembelajaran invidual (competitive).

3 Undang-Undang Republik Indonesia No.20 Tahun 2003, Op cit.
Identifikasi Masalah

Berdasarkan latar belakang diatas timbul beberapa permasalahan yang menyebabkan rendahnya hasil belajar Fiqih di Madrasah Tsanawiyah, antara lain: Apakah strategi pembelajaran yang diberikan guru mempengaruhi hasil belajar Fiqih? Apakah sistem penilaian yang dikembangkan sudah dapat menunjukkan hasil belajar Fiqih? Apakah IQ siswa berpengaruh terhadap hasil belajar Figh? Apakah daya juang siswa terhadap pelajaran Fiqih mempengaruhi hasil belajar Fiqih? Apakah kemampuan awal Fiqih siswa berpengaruh terhadap hasil belajar Fiqih? Apakah percaya diri berpengaruh terhadap hasil belajar Fiqih? Apakah lingkungan sekolah berpengaruh terhadap hasil belajar Fiqih? Apakah kondisi sosial ekonomi orang tua berpengaruh terhadap hasil belajar Fiqih? Apakah sarana belajar berpengaruh terhadap hasil belajar Fiqih?, kemampuan guru berpengaruh terhadap hasil belajar Fiqih?, lingkungan masyarakat berpengaruh terhadap hasil belajar Fiqih? Apakah minat belajar siswa mempengaruhi hasil belajar Fiqih?

\section{Pembatasan Masalah}

Banyak masalah yang dapat diteliti berkaitan dengan proses dan hasil belajar. Agar penelitian ini fokus, maka ruang lingkup masalah penelitian dibatasi pada variabel-variabel yang akan diteliti, yaitu aspek yang berkenaan dengan strategi pembelajaran cooperatif dan competitif serta minat belajar siswa terhadap mata pelajaran Fiqh.

\section{Perumusan Masalah}

Berdasarkan identifikasi masalah dan pembatasan masalah, maka masalah penelitian ini dapat dirumuskan sebagai berikut:

1. Apakah terdapat perbedaan hasil belajar Fiqih antara yang memakai strategi 
pembelajaran kooperatif dan strategi pembelajaran kompetitif?

2. Apakah terdapat perbedaan hasil belajar Fiqih antara yang memakai strategi pembelajaran kooperatif dan strategi pembelajaran kompeietif bagi siswa yang memiliki minat belajar tinggi?

3. Apakah terdapat perbedaan hasil belajar Fiqih antara yang memakai strategi pembelajaran kooperatif dan strategi pembelajaran kompetitif bagi siswa yang memiliki minat belajar rendah?

4. Apakah terdapat pengaruh interaksi antara strategi pembelajaran dan minat belajar terhadap hasil belajar Fiqih?

\section{KAJIAN TEORITIK}

Hasil Belajar Fiqih

Belajar merupakan kegiatan individu untuk memperoleh pengetahuan prilaku dan keterampilan dengan cara melakukan aktivitas-aktivitas belajar. Gagne mendefinisikan belajar sebagai suatu proses untuk memperoleh motivasi dalam pengetahuan, keterampilan, kebiasaan dan tingkah laku serta penguasaan pengetahuan atau keterampilan yang diperoleh dari pembelajaran. ${ }^{4}$

Sedang hasil belajar, atau yang dikenal dengan istilah learning outcomes adalah seluruh kecakapan dan hasil yang dicapai melalui proses belajar mengajar di sekolah yang dinyatakan dengan angka-angka atau nilai-nilai yang diukur dengan tes hasil belajar. Hasil belajar merupakan kemampuan internal yang meliputi: (1) keterampilan intelektual, yaitu kemampuan yang membuat seseorang menjadi kompeten terhadap suatu subyek sehingga ia dapat membuat klasifikasi, mengidentifikasi, mendemonstrasikan, dan menggeneralisasi suatu gejala. (2) strategi kognitif, yaitu

4 Robert M. Gagne \& Leslie J. Briggs. 1979. Principles of Instructional Desig. New York: Holt Rinehart and Winston, hal. 53. kemampuan seseorang untuk dapat mengontrol aktivitas intelektualnya dalam mengatasi masalah baru yang dihadapinya. (3) informasi verbal, yaitu kemampuan seseorang untuk menggunakan bahasa lisan maupun tulisan dalam mengungkapkan suatu masalah. (4) keterampilan motoris, yaitu kemampuan seseorang untuk mengkoordinasikan gerakan otot secara teratur dan lancar dalam keadaan sadar, (5) minat, yaitu kecenderungan dalam menerima dan menolak suatu obyek. 5

Hasil belajar adalah perubahan tingkah laku yang disebabkan oleh belajar. Bloom mendefinisikan hasil belajar adalah sebagai hasil perubahan tingkah laku. Menurutnya hasil belajar ini meliputi tiga ranah, yakni ranah kognitif, afektif, dan psikomotor. Ranah kognitif meliputi (1) pengetahuan, (2) pemahaman, (3) aplikasi, (4) analisis, (5) sintesis, dan (6) evaluasi.6 Kemampuan pertama (pengetahuan, pemahaman, dan penerapan/aplikasi) digolongkan sebagai tingkat kognitif rendah,. Kemamuan selanjutnya (analisis, sintesis, dan evaluasi) dikatakan sebagai kemampuan tingkat kognitif tinggi.

Jadi dapat disimpulkan bahwa yang dimaksud dengan hasil belajar dalam penelitian ini adalah kemampuan siswa pada ranah kognitif yang diperoleh setelah mengikuti proses pembelajaran yang terwujud dalam bentuk skor hasil belajar Fiqh.

Mata pelajaran Fiqih dalam kurikulum Madrasah Tsanawiyah adalah salah satu mata pelajaran pendidikan Agama Islam yang diarahkan untuk menyiapkan peserta didik untuk mengenal, memahami, menghayati dan mengamalkan hukum Islam, yang kemudian menjadi dasar pandangan hidupnya (way of life) melalui kegiat-

5 Ibid, hal. 49 - 51.

6 Benjamin S. Bloom (Ed). 1981, Taxonomy of Educational Objective. Handbook 1: Cognitive Domain, New York: Longman Inc, hal. 7. 
an bimbingan, pengajaran, latihan, penggunaan pengalaman dan pembiasaan? Mata pelajaran Fiqih meliputi: Fiqih Ibadah, Fiqih Muamalah, Fiqih Jinayah dan Fiqih Siyasah yang menggambarkan bahwa ruang lingkup Fiqih mencakup terwujudnya keserasian, keselarasan, dan keseimbangan hubungan manusia dengan Allah Swt, dengan ridi sendiri, sesame manusia, makhluk lainnya, maupun lingkungannya (habluminallah wa hablum minannas) ${ }^{8}$.

Empat unsur pokok mata pelajaran Fiqih di MTs. Yaitu: Fiqih Ibadah, Fiqih Muamalah, Fiqih Jinayah dan Fiqih Siyasah. Berdasarkan pengelompokan per unsur, kemampuan dasar mata pelajaran Fiqih di MTs, adalah sebagai berikut: (1). Fiqih Ibadah (thaharah / bersuci, shalat wajib, shalat berjama'ah, shalat jama' dan qashar, shalat darurat, shalat jenazah, shalat sunnah, sujud di luar shalat, dzikir dan do'a, membelanjakan harta di luar zakat, ibadah haji dan umrah, hukum Islam tentang makanan dan minuman, dan aqiqah dan qurban). (2) Fiqih Muamalah (macam-macam muamalah, muamalah di luar jual beli, kewajiban terhadap orang sakit, jenazah dan ziarah kubur serta pergaulan remaja sesuai dengan syariat Islam.) (3) Fiqih Jinayah (memahami jinayat, hudud dan sangsinya), (4) Fiqih Siyasah (mematuhi undang-undang Negara dan syariat islam, kepemimpinan dalam Islam, dan memelihara, mengolah lingkungan dan kesejahteraan sosial). ${ }^{9}$

Kompetensi untuk kelas VIII adalah kemampuan membiasakan untuk mencari, menyerap, menyampaikan, dan menggunakan informasi tentang sujud, dzikir dan do'a, haji dan umrah, qurban

7 Direktorat Kelembagaan Agama Islam Depatemen Agama RI. 2004. Standar Kompetensi Madrasah Tsanawiyah. Jakarta:. Depatemen Agama $\mathrm{RI},$. hal, 46.

$8 \mathrm{lbid}$

9 lbid. hal. 48 dan aqiqah.10 Dari ko0mpetensi tersebut, untuk kelas VIII semester ganjil kompetensi dasarnya adalah tentang sujud syukur dan tilawah, dzikir dan do'a, puasa nadzar, dan infaq.

Berdasarkan penjelasan di atas, maka yang dimaksud dengan hasil belajar mata pelajaran Fiqih kelas VIII semester ganjil adalah kemampuan siswa pada mata pelajaran Fiqih yang diukur dengan tes yang meliputi ranah kognitif aspek pengetahuan, pemahaman dan aplikasi dari materi Fiqih antara lain: (1) sujud dan tilawah, (2) dzikir dan do'a, (3) puasa nadzar, dan (4) infaq

\section{Strategi pembelajaran Kooperatif}

Kooperatif adalah kegiatan belajar mengajar dalam kelompok-kelompok kecil, di mana siswa belajar dan bekerjasama untuk mendapatkan pengalaman belajar yang optimal baik pengalaman individu maupun kelompok. Pelaksanaan prosedur Kooperatif merupakan suatu struktur tugas bersama dalam suasana kebersamaan diantara sesama anggora kelompok ${ }^{11}$

Johnson menjelaskan bahwa Kooperatif adalah suatu hubungan antara kelompok siswa yang saling bekerjasama untuk mendapatkan hasil yang optimal.12 Menurut Lie terdapat lima unsur model Kooperatif yaitu: (1) saling ketergantungan positif, (2) tanggungjawab perseorangan, (3) tatap muka, (4) komunikasi antara anggota, dan (5) evaluasi proses kelompok.13 Sejalan dengan itu, Johnson menjelaskan bahwa unsur-unsur Kooperatif terdiri dari (1) saling ketergantungan positif, dimana semua anggota kelompok saling bekerjasama untuk

10 lbid. hal. 56

11 Etin Solihatin dan Raharjo. 2007. Cooperative Learning.Jakarta: Bumi Aksara, hal, 4q.

12 Roger T. Johnson dan David W. Johnson. Cooperative Learning, hal. 1

13 lbid, hal, 31 
mencapai tujuan, (2) interaksi tatap muka yang cukup, (3) tanggungjawab individu dalam mengembangkan tujuan kelompok, (4) pemanfaatan seluruh kemampuan anggota kelompok, dan (5) proses pengembangan kelompok ${ }^{14}$

Strategi Kooperatif merupakan suatu strategi pembelajaran dalam kelompok kecil yang terdiri dari siswa yang memiliki kemampuan yang berbeda untuk mengembangkan kemampuan dalam mempelajari suatu objek. Setiap anggota kelompok saling bekerjasama dalam meningkatkan kemajuan belajar dan membantu keberhasilan seluruh anggota kelompok ${ }^{15}$ sehingga dengan model Kooperatif siswa termotivasi untuk belajar lebih aktif dalam pembelajaran serta dapat mengatasi permasalahan dan bekerjasama dalam meningkatkan perkembangan belajar

Oleh sebab itu pada strategi pembelajaran Kooperatif, guru tidak lagi berperan sebagai satu-satunya nara sumber dalam proses belajar mengajar, tetapi guru lebih banyak berperan sebagai mediator, stabilisator, dan manajer pembelajaran. Iklim belajar yang berlangsung dalam suasana keterbukaan dan demokratis akan memberikan kesempatan yang optimal bagi siswa untuk memperoleh informasi yang lebih banyak mengenai materi yang dibelajarkan. Sekaligus melatih minat dan keterampilan sosialnya sebagai bekal dalam kehidupannya di masyarakat, sehingga perolehan dan hasil belajar siswa akan semakin meningkat.

Jadi kesimpulannya model Kooperatif adalah strategi pembelajaran dalam kelompok kecil yang terdiri dari siswa yang memiliki kemampuan yang berbeda, mengembangkan kemampuan dalam mempelajari suatu objek secara bersama-

14 Roger T. and David W. Johnson. An Overview of Cooperative Learning. http.www. google, hal. 2

15 Ricard D. Parsons. Educaional Psychology. A Practitioner Model of Teaching. London: Watsworth, hal. 197 sama dengan cara saling bekerjasama. Sehingga pada proses Kooperatif ini siswa menjadi termotivasi untuk belajar lebih aktif dan kreatif

\section{Strategi Pembelajaran Kompetitif}

Strategi pembelajaran kompetitif merupakan salah satu jenis strategi pembelajaran yang bersifat nonkooperatif dimana para siswa belajar dan menyelesaikan tugasnya secara individu atau mandiri. Jenis pembelajaran seperti ini sudah terbiasa dilakukan dalam praktik pembelajaran disekolahsekolah kita. Dikatakan kompetitif karena penekanannya pada sistem ganjaran yang bersifat individual. Dasar pembelajarannya adalah guru memberikan arahan pada proses pembelajaran secara sendiri-sendiri tanpa ada interaksi dengan teman-teman sekelasnya.

Johnson dan Johnson mengatakan bahwa tujuan strategi pembelajaran kompetitif adalah memaksimalkan kinerja akademis masing-masing siswa demi mencapai prestasi tertinggi yang mungkin hanya bisa dicapai oleh satu atau beberapa siswa saja. Untuk mencapai tujuan itu siswa dipacu semangatnya untuk berkompetisi dengan asumsi bahwa teman-teman sekelasnya adalah saingan yang harus dikalahkannya ${ }^{16}$.

Pembelajaran kompetitif adalah setiap siswa bisa belajar sendiri tanpa bantuan dari pengajar. Di samping itu setiap anak memiliki kebiasaan, kemampuan, minat dan bakat yang berbeda satu sama lain. Oleh karena itu setiap anak perlu mendapatkan perhatian dan kesempatan khusus agar kompetensi masing-masing anak dapat dikembangkan seoptimal mungkin. ${ }^{17}$

Sementara itu pendapat Good dan Brophy mengatakan kesempatan untuk

16 David W. Johnson, and Roger T. Johnson. 1996. Cooperation and the Use of technology, New York McMillian Library Reference USA, hal. 130.

17 Lie, Anita Cooperattive Learning: Mempraktikkan Cooperative Learning di Ruang-Ruang Kelas Terjemahan, Jakarta: Grasindo, hal.26-27 
berkompetisi secara individual dapat memberikan insentif dan kegairahan bagi kegiatan-kegiatan dikelas, apakah kompetisi untuk mendapatkan hadiah, pujian atau kepuasan semata ${ }^{18}$.

Dalam pembelajaran kompetitif persaingan di kelas sangat ditekankan karena orientasi belajar adalah hasil. Dengan demikian hasil yang diharapkan adalah kinerja atau prestasi individu yang maksimal. Dan alat untuk mendukung system pembelajaran ini adalah eksistensi dari evaluasi dan system ganjaran.

Menurut Johnson dan Johnson evaluasi merupakan hal yang sangat penting karena menjadi tolak ukur untuk menilai kinerja siswa dari yang paling baik kepada yang paling jelek ${ }^{19}$.

Dari uraian di atas maka dapat ditarik kesimpulan strategi pembelejaran kompetitif adalah pembelajaran pencapaian prestasi yang setinggi-tingginya melalui persaingan dan kompetisi dengan teman-temannya.

\section{Minat Belajar Fiqih}

Minat adalah kesiapan merespon yang sifatnya positif atau negatif terhadap objek atau situasi secara konsisten. Minat merupakan kekuatan yang mendorong individu dalam memberi perhatian terhadap sesuatu kegiatan tertentu. ${ }^{20}$ Minat menjadi sebab kegiatan dan sebab partisipasi dalam kegiatan. Selanjutnya lebih ditekankan bahwa minat adalah kecenderungan untuk memilih suatu kegiatan dibandingkan dengan kegiatan lainnya. ${ }^{21}$ Dengan adanya

18 Thomas L. Good, and Jere E. Brophy. 1990. Educational Psychology, A Realistic Approach New York: Longman, hal. 320 - 321.

19 Johnson. Op.cit, hal. 40.

20 Lester D. Crow \& Alice Crow. 1973. Educational Psychology. New York: American Book Co., hal.. 248.

21 Robert Slavin. 1994,. Principles Educational Psychology. Massachusset: Allyn an Bacon Publishing hal. 369. minat akan membuat siswa mempunyai motivasi untuk belajar, karena minat dapat diklasifikasikan sebagai motivasi intrinsik yang menyebabkan adanya perasaan senang, tertarik, dan puas karena terpenuhi kebutuhannya. 22

Minat seseorang terhadap pelajaran tertentu akan menyebabkan perhatian individu terhadap mata pelajaran tersebut menjadi besar. Hal senada dikemukakan bahwa salah satu faktor yang mempengaruhi perhatian siswa terhadap pelajarannya adalah minat. Memberikan stimulus yang sesuai dengan sikap siswa jelas akan lebih mudah menarik perhatiannya untuk belajar.23

Bukti adanya minat dapat dilihat dari perhatian yang dapat ditunjukkan seseorang terhadap obyek yang disenanginya. Rumusan yang sama menyatakan bahwa minat sebagai pemusatan tenaga psikis yang tertuju kepada obyek, serta menentukan banyak sedikitnya kekuatan yang menyertai sesuatu aktivitas yang dilakukan. ${ }^{24}$ Oleh karena itu, guru yang baik perlu mengetahui terlebih dahulu apa saja yang kiranya menarik perhatian siswanya. Pada umumnya, setiap stimulus yang diterima oleh panca indera seseorang akan mampu menarik perhatiannya untuk mengetahui lebih lanjut stimulus tersebut. ${ }^{25}$

Minat mengandung empat hal pokok, yaitu (1) adanya perasaan senang dalam diri orang yang memberikan perhatian terhadap obyek tertentu, (2) adanya ketertarikan terhadap suatu obyek tertentu, (3) adanya kecenderungan berusaha lebih aktif, dan

22 Herbert J. Klausmeier. 1985. Educational Psychology. New york: Harper \& Row Publishers, hal, $229-230$.

23 Frederick J. McDonald. 1968. Educational Psychology California: Publkishing Company Inc., hal. 669.

24 Suryabrata, 0p. cit., hal. 7.

25 Journal. 1998. http.www.enc.org/reform/ journals/ENC2280/280024413.htm 
(4) adanya seleksi untuk bebas memilih suatu obyek tertentu. 26

Minat seseorang tidak hanya mencerminkan perasaan positif yang menyebabkan orang tersebut melakukan sesuatu dengan senang, tetapi juga mencakup suatu pengetahuan tentang aktivitas dan adanya kemampuan untuk melaksanakan aktivitas tersebut. Hal ini sesuai dengan pendapat yang menyatakan bahwa minat pada umumnya terbentuk melalui pengalaman. ${ }^{27}$ Oleh sebab itu semua pengalaman belajar siswa perlu berhubungan dengan minatnya, karena tanpa adanya minat seseorang sangat sulit untuk mempelajari sesuatu.

Berkaitan dengan mata pelajaran Fiqih, pernyataan di atas, minat belajar siswa dirumuskan sebagai perhatian dan ketertarikan seseorang yang mengarah pada aktivitas belajar. Minat siswa terhadap belajar Fiqh dapat diukur berdasarkan indikator-indikator (1) perhatian siswa terhadap belajar Fiqih, (2) Ketertarikan dalam belajar Fiqih, (3) Keaktifan untuk belajar Fiqih, dan (4) Penggunaan waktu belajar Fiqih.

\section{Kajian Penelitian yang relevan}

Sofia Dewi dalam penelitian berkenaan strategi pembelajaran terhadap keberhasilan belajar matematika menemukan bahwa strategi pembelajaran kolaboratif memiliki skor yang lebih tinggi dari pada strategi pembelajaran kompetitif. Saran terhadap hasil penelitian tentang strategi pembelajaran karena terbukti berpengaruh terhadap peningkatan hasil belajar siswa maka guru dalam proses belajar mengajar perlu memilih strategi yang tepat.28 Mengutip

26 Jeanne Ellis Ormrod, Educational Psychology Developing Learners, New Yersey: Pearson Education Inc., hal. 400 .

27 Skinner, op. cit., hal. 325

28 Sofia Dewi. 2008. Pengaruh Strategi Pembelajaran Kolaboratif dengan Strategi Pembelajaran dari tulisan Sofia Dewi juga dalam tesisnya menyebutkan bahwa Hasil meta-analisis tentang pengaruh strategi pembelajaran kolaboratif mempengaruhi hasil belajar selalu konsisten. Tinjauan Johnshon dkk terhadap penelitian selama 9 tahun menunjukkan bahwa Cooperative meningkatkan hasil belajar relatif terhadap pekerjaan individual. Lebih jauh Johnson dkk dalam penelitian terbarunya menemukan hasil serupa, dimana mereka mengkaji 168 penelitian mulai tahun 1924-1997, sedangkan Spinger dkk juga menemukan hasil serupa berdasarkan kajian terhadap 37 penelitian untuk bidang ilmu pengetahuan alam, matematika, rekayasa dan teknologi. ${ }^{29}$

\section{METODOLOGI}

Penelitian ini menggunakan metode Eksperimen treatmen by level dengan membagi dua kelompok sasaran yang terdiri dari satu kelompok memiliki minat belajar tinggi dan satu kelompok memiliki minat belajar rendah berdasarkan hasil kuesioner yang diisi oleh siswa.

Dari dua kelompok yang memiliki minat belajar yang berbeda dibuat dua kelompok eksperimen dimana tiap kelompok eksperimen terdiri dari siswa-siswa yang memiliki minat belajar tinggi dan rendah. Kepada kedua kelompok tersebut diberikan proses pembelajaran yang berbeda, kelompok satu menggunakan strategi pembelajaran Kooperatif dan kelompok yang lain menggunakan strategi pembelajaran competitif learning. Perlakuan (treatment) diberikan kepada unit eksperimen melalui "level" dimana level berimplikasi pada besaran atau kekuatan (magnitude). "level" juga dapat digunakan pada variabel kategoris. 30

Kompetitif dan kemampuan awal terhadap Hasil Belajar Matematika, Program Pasca Sarjana UNJ, hal. 104

29 Ibid, hal.42

30 Design of Experiment and Anova, 2007, hal.17 (http;//www.stats gla.ac.uk/steps/glossary/anova.html). 
Populasi

Populasi target penelitian adalah siswa-siswi MTs $\mathrm{N}$ di wilayah Jakarta Timur, dimana seluruh siswa telah menerima dan seluruh mata pelajaran berdasarkan kurikulum yang sama yaitu KTSP.

Sedangkan populasi terjangkaunya adalah siswa MTs kelas VIII (delapan) sebanyak 6 kelas yang tersebar pada 2 sekolah (MTsN) yaitu MTs.N 17 Pasar Rebo Jakarta Timur sebanyak 3 kelas dan MTs.N 34 Pasar Rebo Jakarta Timur sebanyak 3 kelas.

\section{Teknik Pengumpulan data}

Dari populasi diambil sampel dengan menggunakan multistage random sampling, yaitu dalam menentukan sampel secara bertahap. Tahap pertama yaitu menentukan wilayah penelitian yaitu di Jakarta Timur, Tahap kedua merandom 2 MTs.N dari sebanyak MTs.N yang ada di wilayah Jakarta Timur digunakan untuk eksperimen. Dari 2 MTs.N yang terpilih, masing-masing seluruh siswa kelas VIII diidentifikasi untuk menentukan satu kelas untuk eksperimen dengan strategi pembelajaran kooperatif dan satu kelas untuk eksperimen dengan strategi pembelajaran kompetitif. Kepada seluruh siswa dari kelas yang terpilih diberikan angket dan untuk mengklasifikasikan siswa ke dalam kategori memiliki kecenderungan minat belajar tinggi atau memiliki kecenderungan minat belajar rendah.

\section{Instrumen Penelitian}

Penelitian ini menggunakan tes untuk mendapatkan nilai belajar mata pelajaran Fiqih, yang meliputi ranah kognitif dalam aspek pengetahuan, pemahaman dan aplikasi dari materi Fiqih antara lain: (1) sujud dan tilawah, (2) dzikir dan do'a, (3) puasa nadzar, dan (4) infaq
Sedang untuk mengukur minat belajar berdasarkan indikator-indikator (1) perhatian siswa terhadap belajar Fiqih, (2) Ketertarikan dalam belajar Fiqih, (3) Keaktifan untuk belajar Fiqih, dan (4) Penggunaan waktu belajar Fiqih.

Teknik Analisis Data

Sebelum dianalisis, terhadap data yang diperoleh dilakukan pengujian persyaratan analisis sebagai prasyarat penggunaan teknik analisis statistik. Selanjutnya baru dilakukan pengujian Hipotesis.

Teknik pengujian persyaratan analisis

Uji persyaratan analisis yang digunakan adalah uji normalitas dan uji homogenitas varians. Uji normalitas data dimaksudkan untuk menentukan normal tidaknya distribusi data hasil penelitian. Teknik pengujian normalitas yang digunakan adalah uji Lilliefors, Data dikatakan normal apabila harga $L_{\text {hitung }}<L_{\text {tabel. }}$

Sedangkan uji homogenitas dimaksudkan untuk mengetahui bahwa kelompok berasal dari kelompok yang homogen. uji homogenitas variansi populasi untuk kelompok data dilakukan dengan menggunakan uji Bartlett. Data dikatakan homogen apabila harga $\mathrm{C}^{2}$ hitung $<\mathrm{C}^{2}$ tabel .

Teknik pengujian Hipotesis

Pengujian Hipotesis penelitian ini menggunakan teknik analisis varians (ANAVA) dua jalur dengan rancangan faktorial $2 \times 2$. Taraf kepercayaan yang digunakan untuk pengujian tersebut adalah $a=0,05$. Apabila pengujian Hipotesis signifikan dilanjutkan dengan uji Tukey. Uji Tukey digunakan untuk melihat efek interaksi yang lebih baik. 


\section{TEMUAN DAN PEMBAHASAN}

\section{Deskripsi Data}

Hasil Belajar Fiqih Kelompok Siswa yang Diberi Perlakuan Pembelajaran Kooperatif $\left(A_{1}\right)$

Berdasarkan hasil analisis data tentang hasil belajar Fiqih siswa diperoleh dari skor yang dicapai pada tes Fikih pada kelompok siswa yang diberi perlakuan pembelajaran kooperatif sebanyak 20 orang siswa secara empiris mempunyai nilai rentangan skor 29 , skor terendah 62 , skor tertinggi 91 , skor rata-rata 76,5 , simpangan baku 9,15 . modus 78 dan median 78. Penyajian data melalui tabel distribusi frekuensi dengan banyak kelas 6 dan interval kelas 5, sebagai berikut:

Tabel 1:

Distribusi Frekuensi Hasil Belajar Fiqih Kelompok Siswa yang Diberi Perlakuan pembelajaran kooperatif $\left(A_{1}\right)$

\begin{tabular}{|c|c|c|c|}
\hline No. & $\begin{array}{c}\text { Interval } \\
\text { Kelas }\end{array}$ & $\begin{array}{c}\text { Frekuensi } \\
\text { Absolut }\end{array}$ & $\begin{array}{c}\text { Frekuensi } \\
\text { Relatif (\%) }\end{array}$ \\
\hline 1 & $62-66$ & 4 & 5.00 \\
2 & $67-71$ & 2 & 5.00 \\
3 & $72-76$ & 2 & 10.00 \\
4 & $77-81$ & 6 & 30.00 \\
5 & $82-86$ & 3 & 20.00 \\
6 & $87-91$ & 3 & 30.00 \\
\hline & Jumlah & 20 & 100,00 \\
\hline
\end{tabular}

Hasil Belajar Fiqih Kelompok Siswa yang Diberi Perlakuan Pembelajaran Kompetitif $\left(A_{2}\right)$

Berdasarkan hasil analisis data tentang hasil belajar Fiqih siswa diperoleh dari skor yang dicapai pada tes Fikih pada kelompok siswa yang diberi perlakuan pembelajaran kompetitif 20 orang siswa secara empiris mempunyai nilai rentangan skor 20, skor terendah 62 , skor tertinggi 82 , skor rata-rata 72,95, simpangan baku 9,15, modus 75 dan median 74. Penyajian data melalui tabel distribusi frekuensi dengan banyak kelas 6 dan interval kelas 4, sebagai berikut:
Tabel 2: Distribusi Frekuensi Hasil Belajar Fiqih Kelompok Siswa yang Diberi Perlakuan Pembelajaran Kompetitif $\left(A_{2}\right)$

\begin{tabular}{|c|c|c|c|}
\hline No. & $\begin{array}{c}\text { Interval } \\
\text { Kelas }\end{array}$ & $\begin{array}{c}\text { Frekuensi } \\
\text { Absolut }\end{array}$ & $\begin{array}{c}\text { Frekuensi } \\
\text { Relatif (\%) }\end{array}$ \\
\hline 1 & $62-65$ & 2 & 10,00 \\
2 & $66-69$ & 3 & 15,00 \\
3 & $70-73$ & 5 & 25,00 \\
4 & $74-77$ & 6 & 30,00 \\
5 & $80-83$ & 4 & 20,00 \\
6 & $84-85$ & 0 & 0 \\
\hline & Jumlah & 20 & 100,00 \\
\hline
\end{tabular}

Hasil Belajar Fiqih Kelompok Siswa yang Memiliki Minat belajar Fiqih Tinggi $\left(B_{1}\right)$

Berdasarkan hasil analisis data tentang hasil belajar Fiqih siswa diperoleh dari skor yang dicapai pada tes Fikih pada kelompok siswa yang memiliki minat belajar Fikih tinggi 20 orang siswa secara empiris mempunyai nilai rentangan skor 27 , skor terendah 64 , skor tertinggi 91 , skor rata-rata 76,90, simpangan baku 7,70, modus 78 dan median 76,5 . Penyajian data melalui tabel distribusi frekuensi dengan banyak kelas 6 dan interval kelas 5 sebagai berikut:

Tabel 3: Distribusi Frekuensi Hasil Belajar Fiqih Kelompok Siswa yang Memiliki Minat belajar Fikih Tinggi $\left(B_{1}\right)$

\begin{tabular}{|c|c|c|c|}
\hline No. & $\begin{array}{c}\text { Interval } \\
\text { Kelas }\end{array}$ & $\begin{array}{c}\text { Frekuensi } \\
\text { Absolut }\end{array}$ & $\begin{array}{c}\text { Frekuensi } \\
\text { Relatif (\%) }\end{array}$ \\
\hline 1 & $64-68$ & 3 & 15.00 \\
2 & $69-73$ & 5 & 25.00 \\
3 & $74-78$ & 6 & 30.00 \\
4 & $79-83$ & 3 & 15.00 \\
5 & $84-88$ & 1 & 5.00 \\
6 & $89-93$ & 2 & 10.00 \\
\hline & Jumlah & & 100,00 \\
\hline
\end{tabular}

Hasil Belajar Fiqih Kelompok Siswa yang Memiliki Minat belajar Fiqih Rendah $\left(\mathrm{B}_{2}\right)$

Berdasarkan hasil analisis data tentang hasil belajar Fiqih siswa diperoleh dari skor yang dicapai pada tes Fiqih pada kelompok siswa yang memiliki minat belajar Fikih rendah 20 orang siswa secara empiris mempunyai nilai rentangan skor 20, skor terendah 62 skor tertinggi 82, skor rata-rata 72,20 simpangan baku 6,72. modus 62 dan median 75. Penyajian data melalui tabel 
distribusi frekuensi dengan banyak kelas 6 dan interval kelas 3 , sebagai berikut:

Tabel 4: Distribusi Frekuensi Hasil Belajar Fiqih Kelompok Siswa yang Memiliki Minat belajar Fiqih Rendah $\left(B_{2}\right)$

\begin{tabular}{|c|c|c|c|}
\hline No. & $\begin{array}{c}\text { Interval } \\
\text { Kelas }\end{array}$ & $\begin{array}{c}\text { Frekuensi } \\
\text { Absolut }\end{array}$ & $\begin{array}{c}\text { Frekuensi } \\
\text { Relatif (\%) }\end{array}$ \\
\hline 1 & $62-65$ & 5 & 25.00 \\
2 & $66-69$ & 2 & 10.00 \\
3 & $70-74$ & 2 & 10.00 \\
4 & $75-78$ & 8 & 40.00 \\
5 & $79-82$ & 3 & 15.00 \\
6 & $83-86$ & 0 & 0.00 \\
\hline & Jumlah & 20 & 100,00 \\
\hline
\end{tabular}

Hasil Belajar Fiqih Kelompok Siswa yang Diberi Perlakuan pembelajaran kooperatif, Bagi Siswa yang Memiliki Minat belajar Fiqih Tinggi $\left(A_{1} B_{1}\right)$

Berdasarkan hasil analisis data tentang hasil belajar Fiqih siswa diperoleh dari skor yang dicapai pada tes Fiqih pada kelompok siswa yang diberi perlakuan pembelajaran kooperatif, bagi siswa yang memiliki minat belajar Fikih tinggi 10 orang siswa secara empiris mempunyai nilai rentangan skor 16 , skor terendah 75 , skor tertinggi 91 , skor rata-rata 82,6 , simpangan baku 5,70 . modus 78 dan median 82. Penyajian data melalui tabel distribusi frekuensi dengan banyak kelas 5 dan interval kelas 3, sebagai berikut:

Tabel 5: Distribusi Frekuensi Hasil Belajar Fiqih Kelompok Siswa yang Diberi Perlakuan pembelajaran kooperatif, Bagi Siswa yang Memiliki Minat belajar Fiqih Tinggi $\left(A_{1} B_{1}\right)$

\begin{tabular}{|c|c|c|c|}
\hline No. & $\begin{array}{c}\text { Interval } \\
\text { Kelas }\end{array}$ & $\begin{array}{c}\text { Frekuensi } \\
\text { Absolut }\end{array}$ & $\begin{array}{c}\text { Frekuensi } \\
\text { Relatif (\%) }\end{array}$ \\
\hline 1 & $75-77$ & 1 & 10,00 \\
2 & $78-80$ & 3 & 30,00 \\
3 & $81-83$ & 3 & 30,00 \\
4 & $84-86$ & 0 & 0,00 \\
5 & $87-91$ & 3 & 30,00 \\
\hline & Jumlah & 10 & 100,00 \\
\hline
\end{tabular}

Hasil Belajar Fiqih Kelompok Siswa yang Diberi Perlakuan pembelajaran kooperatif, Bagi Siswa yang Memiliki Minat belajar Fiqih Rendah $\left(A_{1} B_{2}\right)$

Berdasarkan hasil analisis data tentang hasil belajar Fiqih siswa diperoleh dari skor yang dicapai pada tes Fikih pada kelompok siswa yang diberi perlakuan pembelajaran kooperatif, bagi siswa yang memiliki minat belajar Fiqih rendah secara empiris mempunyai nilai rentangan skor 14 , skor terendah 64, skor tertinggi 78 , skor ratarata 71, simpangan baku 4,22. modus 67 dan median 72 Penyajian data melalui tabel distribusi frekuensi dengan banyak kelas 5 dan interval kelas 3, sebagai berikut:

Tabel 6: Distribusi Frekuensi Hasil Belajar Fiqih Kelompok Siswa yang Diberi Perlakuan pembelajaran kooperatif, Bagi Siswa yang Memiliki Minat belajar Fiqih Rendah $\left(A_{1} B_{2}\right)$

\begin{tabular}{|c|c|c|c|}
\hline No. & $\begin{array}{c}\text { Interval } \\
\text { Kelas }\end{array}$ & $\begin{array}{c}\text { Frekuensi } \\
\text { Absolut }\end{array}$ & $\begin{array}{c}\text { Frekuensi } \\
\text { Relatif (\%) }\end{array}$ \\
\hline 1 & $64-66$ & 1 & 10,00 \\
2 & $67-69$ & 3 & 30.00 \\
3 & $70-72$ & 2 & 20,00 \\
4 & $73-75$ & 3 & 30,00 \\
5 & $76-79$ & 1 & 10,00 \\
\hline & Jumlah & 10 & 100,00 \\
\hline
\end{tabular}

Hasil Belajar Fiqih Kelompok Siswa yang Diberi Perlakuan Pembelajaran Kompetitif, Bagi Siswa yang Memiliki Minat belajar Fiqih Tinggi $\left(A_{2} B_{1}\right)$

Berdasarkan hasil analisis data tentang hasil belajar Fiqih siswa diperoleh dari skor yang dicapai pada tes Fiqih pada kelompok siswa yang diberi perlakuan pembelajaran kooperatif, bagi siswa yang memiliki minat belajar Fikih rendah secara empiris mempunyai nilai rentangan skor 17 , skor terendah 62 , skor tertinggi 79 , skor rata-rata 69,50 , simpangan baku 6,98. modus 62 dan median 69. Penyajian data melalui tabel distribusi frekuensi dengan banyak kelas 5 dan interval kelas 4, sebagai berikut: 
Tabel 7: Distribusi Frekuensi Hasil Belajar Fiqih Kelompok Siswa yang Diberi Perlakuan Pembelajaran kompetitif, Bagi Siswa yang Memiliki Minat belajar Fiqih Tinggi $\left(A_{2} B_{1}\right)$

\begin{tabular}{|c|c|c|c|}
\hline No. & $\begin{array}{c}\text { Interval } \\
\text { Kelas }\end{array}$ & $\begin{array}{c}\text { Frekuensi } \\
\text { Absolut }\end{array}$ & $\begin{array}{c}\text { Frekuensi } \\
\text { Relatif (\%) }\end{array}$ \\
\hline 1 & $62-65$ & 4 & 40,00 \\
2 & $66-69$ & 2 & 20,00 \\
3 & $70-73$ & 1 & 10,00 \\
4 & $74-77$ & 3 & 30,00 \\
5 & $78-81$ & 0 & 0,00 \\
\hline & Jumlah & 10 & 100,00 \\
\hline
\end{tabular}

Hasil Belajar Fiqih Kelompok Siswa yang Diberi Perlakuan Pembelajaran kompetitif, Bagi Siswa yang Memiliki Minat belajar Fiqih Rendah $\left(A_{2} B_{2}\right)$

Berdasarkan hasil analisis data tentang hasil belajar Fiqih siswa diperoleh dari skor yang dicapai pada tes Fiqih pada kelompok siswa yang diberi perlakuan pembelajaran kompetitif, bagi siswa yang memiliki minat belajar Fiqih rendah siswa secara empiris mempunyai nilai rentangan skor 20, skor terendah 62 , skor tertinggi 82 , skor rata-rata 74,90, simpangan baku 5,51, modus 75 dan median 75,50 . Penyajian data melalui tabel distribusi frekuensi dengan banyak kelas 5 dan interval kelas 4, sebagai berikut:

Tabel 8: Distribusi Frekuensi Hasil Belajar Fiqih Kelompok Siswa yang Diberi Perlakuan Pembelajaran kompetitif, Bagi Siswa yang Memiliki Minat belajar Fiqih Rendah $\left(A_{2} B_{2}\right)$

\begin{tabular}{|c|c|c|c|}
\hline No. & $\begin{array}{c}\text { Interval } \\
\text { Kelas }\end{array}$ & $\begin{array}{c}\text { Frekuensi } \\
\text { Absolut }\end{array}$ & $\begin{array}{c}\text { Frekuensi } \\
\text { Relatif (\%) }\end{array}$ \\
\hline 1 & $62-65$ & 1 & 10,00 \\
2 & $66-69$ & 0 & 0,00 \\
3 & $70-73$ & 1 & 10,00 \\
4 & $74-77$ & 5 & 50,00 \\
5 & $78-82$ & 3 & 30,00 \\
\hline & Jumlah & 10 & 100 \\
\hline
\end{tabular}

Pembahasan

Hasil pengujian Hipotesis membuktikan bahwa hasil belajar Fiqih siswa pada kedua perlakuan memberikan perbedaan yang sangat signifikan. Dan melalui uji lan- jut terbukti bahwa hasil belajar Fiqih siswa yang diberi perlakuan pembelajaran kooperatif lebih tinggi dibandingkan dengan siswa yang diberi perlakuan pembelajaran kompetitif Hasil pengujian pengaruh minat belajar Fiqih siswa juga menunjukkan adanya perbedaan yang signifikan antara kelompok siswa yang memiliki minat belajar Fiqih tinggi dengan siswa yang memiliki minat belajar Fiqih rendah. Hasil belajar Fiqih siswa yang memiliki minat belajar Fiqih tinggi akan lebih tinggi dibandingkan dengan Hasil Belajar Fiqih siswa yang memiliki minat belajar Fiqih rendah.

Hasil diatas didapatkan dari penghitungan dan telah melalui pengujian persyaratan analisis. Yang pertama melalui uji normalitas data hasil belajar Fiqih yang berasal dari populasi adalah berdistribusi normal. Hasil Pengujian Normalitas Data dapat dilihat melalui tabel di bawah ini:

Tabel 9: Hasil Pengujian Normalitas Data

\begin{tabular}{|c|c|c|c|c|}
\hline $\begin{array}{c}\text { Kelompok } \\
\text { Sampel }\end{array}$ & $\begin{array}{c}\text { Jumlah } \\
\text { Sampel }\end{array}$ & $L_{\text {hitung }}$ & $\mathrm{L}_{\text {tabel }}$ & Kesimpulan \\
\hline I & 20 & 0,134 & 0,190 & Normal \\
\hline II & 20 & 0,104 & 0,190 & Normal \\
\hline III & 20 & 0,138 & 0,190 & Normal \\
\hline IV & 20 & 0,165 & 0,190 & Normal \\
\hline V & 10 & 0,190 & 0,258 & Normal \\
\hline VI & 10 & 0,129 & 0,258 & Normal \\
\hline VII & 10 & 0,224 & 0,258 & Normal \\
\hline VIII & 10 & 0,207 & 0,258 & Normal \\
\hline
\end{tabular}

Kedua, melalui uji homogenitas dengan menggunakan uji Barlet keseluruhan kelompok data yang diuji melalui varian yang homogen dan hasilnya keseluruhan kelompok data yang diuji memiliki varians yang homogen, sebagaimana terlihat pada tabel di bawah ini. 
Tabel 10: Hasil Uji Homogenitas Varians Kelompok Data

\begin{tabular}{|l|l|l|l|}
\hline Kelompok & $\mathrm{C}^{2}$ hitung & $\mathrm{C}^{2}$ tabel & Kesimpulan \\
\hline A1 dan A2 & 2,85 & 59,3 & Homogen \\
\hline B1 dan B2 & 0,35 & 59,3 & Homogen \\
\hline $\begin{array}{l}\text { A1B1, A2B1, } \\
\text { A1B2, A2B2 }\end{array}$ & 2,22 & 59,3 & Homogen \\
\hline
\end{tabular}

Dalam penelitian ini berasal dari populasi yang berdistribusi normal dan memiliki varians yang homogen. Dengan demikian maka persyaratan normalitas dan homogenitas data terpenuhi sehingga dapat digunakan Analisis Varians (ANAVA) dalam pengujian Hipotesis penelitian. Hasil Hipotesis dalam penelitian pertama dilakukan menggunakan analisis varians dua jalur, dan hasilnya dapat dirangkum melalui tabel di bawah ini:

Tabel 11: ANAVA Dua Jalur

\begin{tabular}{|c|c|c|c|c|c|c|}
\hline \multirow{2}{*}{$\begin{array}{l}\text { Sumber } \\
\text { Varians }\end{array}$} & \multirow[b]{2}{*}{$\mathrm{dk}$} & \multirow{2}{*}{$\begin{array}{c}\text { Jumlah } \\
\text { Kuadrat } \\
\text { (JK) }\end{array}$} & \multirow{2}{*}{$\begin{array}{l}\text { Rerata Jum- } \\
\text { lah Kuadrat } \\
\text { (RJK) }\end{array}$} & \multirow[b]{2}{*}{$F_{\text {hitung }}$} & \multicolumn{2}{|c|}{$\mathrm{F}_{\text {tabel }}$} \\
\hline & & & & & $a=0,05$ & $\begin{array}{l}a= \\
0,01\end{array}$ \\
\hline \begin{tabular}{|l|} 
Perlakuan \\
Strategi Pem- \\
belajaran (A) \\
\end{tabular} & 1 & 1030.20 & 1030.20 & $31.87^{* *}$ & 4,08 & 7,31 \\
\hline $\begin{array}{l}\text { Minat belajar } \\
\text { Fiqih (B) }\end{array}$ & 1 & 211.60 & 211.60 & $6.55^{*}$ & 4,08 & 7,31 \\
\hline \begin{tabular}{|l|} 
Interaksi (A \\
X B) \\
\end{tabular} & 1 & 722.50 & 722.50 & $22.35^{* *}$ & 4,08 & 7,31 \\
\hline $\begin{array}{l}\text { Antar kelom- } \\
\text { pok Dalam } \\
\text { kelompok } \\
\text { (kekeliruan) }\end{array}$ & $\begin{array}{r}3 \\
36\end{array}$ & $\begin{array}{r}103020 \\
1163.80\end{array}$ & $\begin{array}{r}343.40 \\
32.33\end{array}$ & $\begin{array}{l}- \\
-\end{array}$ & $\begin{array}{l}- \\
-\end{array}$ & - \\
\hline Total direduksi & 39 & 2194.00 & - & - & - & - \\
\hline $\begin{array}{l}\text { Rerata (ko- } \\
\text { reksi) }\end{array}$ & 1 & 222.010 & - & - & - & - \\
\hline TOTAL & 40 & 2416.01 & - & - & - & - \\
\hline
\end{tabular}

Adanya interaksi dan signifikannya pengaruh utama antara strategi pembelajaran dan minat belajar Fiqih dalam analisis varians di atas maka pengujian dilanjutkan dengan menggunakan uji Tukey antara pasangan data guna menentukan rata-rata kelompok mana yang lebih tinggi antara dua kelompok data yang dipasangkan.
Tabel 12: Hasil Uji Tukey antara Kelompok Data

\begin{tabular}{|l|l|l|l|l|l|}
\hline \multirow{2}{*}{ Kelompok } & \multirow{2}{*}{$n$} & \multirow{2}{*}{$\mathrm{Q}_{\text {hitung }}$} & \multicolumn{2}{|l|}{$\mathrm{Q}_{\text {tabel }}$} & Kesimpulan \\
\cline { 5 - 6 } & & & $3=0,05$ & $\mathrm{a}=0,01$ & \\
\hline $\mathrm{A} 1$ - A2 & 40 & $3,45^{*}$ & 2,86 & 3,84 & Signifikan \\
\hline $\mathrm{B} 1$ - B2 & 40 & $7,41^{* *}$ & 2,86 & 3,84 & $\begin{array}{l}\text { Sangat signi- } \\
\text { fikan }\end{array}$ \\
\hline A1B1-A2B1 & 20 & $9,12^{* *}$ & 2,95 & 4,02 & $\begin{array}{l}\text { Sangat signi- } \\
\text { fikan }\end{array}$ \\
\hline A1B2-A2B2 & 20 & $4,25^{*}$ & 2,95 & 4,02 & $\begin{array}{l}\text { Sangat Signi- } \\
\text { fikan }\end{array}$ \\
\hline
\end{tabular}

Hasil pengujian Hipotesis pertama, membuktikan bahwa secara keseluruhan siswa yang belajar dengan pembelajaran kooperatif lebih tinggi hasilnya dibandingkan dengan siswa yang belajar dengan pembelajaran kompetitif. Dalam hal ini dapat dikatakan bahwa untuk mencapai tujuan pembelajaran kooperatif lebih efektif jika dibanding dengan pembelajaran kompetitif. Secara lengkap hasil kuji tukey ditampilkan pada tabel di bawah ini:

Tabel 13: Kesimpulan Uji Tukey

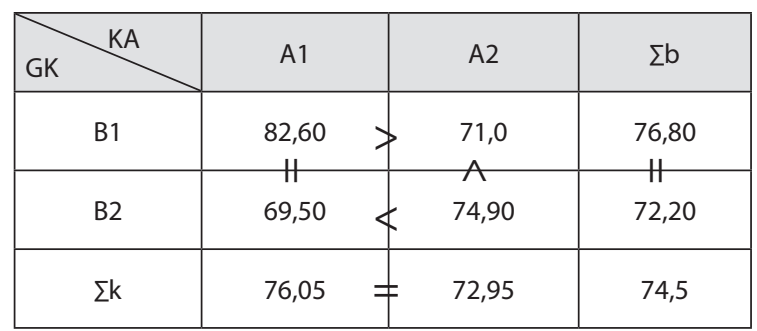

Interaksi antara strategi pembelajaran dengan minat belajar Fiqih

Hasil pengujian Hipotesis yang dilakukan membuktikan bahwa ada interaksi antara model pembelajaran dengan minat belajar Fiqih siswa dan pengaruhnya terhadap hasil belajar Fiqih. Kelompok siswa yang mempunyai minat belajar Fiqih tinggi dan diberi dengan pembelajaran kooperatif mencapai hasil belajar Fiqih yang lebih tinggi jika dibandingkan dengan kelompok siswa yang memiliki minat belajar Fikih tinggi yang diberi pembelajaran kompetitif. Hal ini menunjukkan bahwa pengaruh strategi pembelajaran dengan pendekatan 
pembelajaran kooperatif berhubungan dengan karakteristik siswa yang mengikuti pembelajaran. Sebaliknya, pada kelompok siswa yang memiliki minat belajar Fiqih rendah yang belajar dengan pembelajaran kooperatif mencapai hasil belajar Fiqih yang lebih rendah jika dibanding dengan kelompok siswa yang diberi pembelajaran kompetitif. Hal ini juga menunjukkan bahwa pengaruh pembelajaran kompetitif juga berhubungan dengan karakteristik siswa yang mengikuti pembelajaran Fiqih.

Penjelasan terjadinya interaksi di atas, dapat digambarkan melalui perbandingan rerata skor hasil belajar Fiqih antara empat siswa yang berbeda minat belajar Fiqihnya dan perolehan perlakuan latihan dalam bentuk grafik sebagai berikut:

Gambar 1: Grafik Interaksi Hasil Belajar Fiqih dengan Minat Belajar siswa dan strategi pembelajaran.

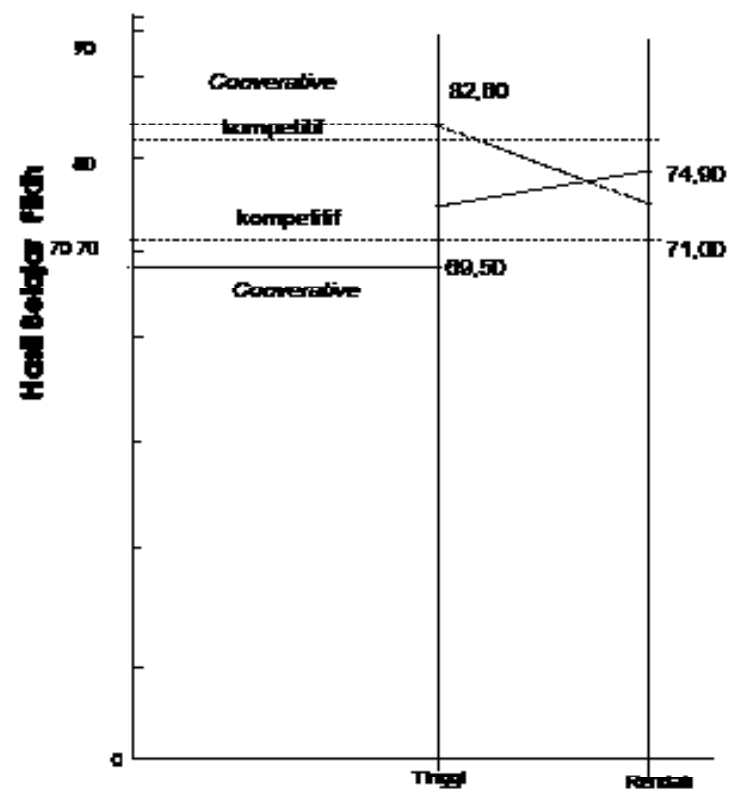

Keterangan:

$\begin{array}{ll}---------- & =\text { Minat belajar Fiqih } \\ ------- & =\text { Pendekatan Pembelajaran }\end{array}$

Gambar di atas memperlihatkan daya pembeda (diskrepansi) yang cukup menyolok antara pengaruh pembelajaran kooperatif yang diberikan pada siswa yang memiliki kecenderungan minat belajar Fiqih tinggi dari yang diberikan pada kelompok siswa yang memiliki minat belajar Fiqih rendah. Demikian juga sebaliknya ada perbedaan antara pengaruh pembelajaran kompetitif yang diberikan pada kelompok siswa yang memiliki minat belajar Fiqih tinggi antara yang diberikan pada kelompok siswa yang memiliki minat belajar Fiqih rendah.

Efektifitas model pembelajaran dengan pembelajaran kooperatif pada kelompok siswa yang memiliki minat belajar Fiqih tinggi, terkait dengan sifat subjek siswa dan model interaksi pembelajaran yang tercipta oleh pembelajaran kooperatif itu sendiri.

Sebaliknya pada siswa yang memiliki minat belajar Fiqih rendah, penggunaan pembelajaran kompetitif dalam pembelajaran Fikih mencapai hasil yang lebih tinggi jika dibandingkan dengan penggunaan pendekatan pembelajaran secara Cooperative. Hal ini memberikan pemahaman bahwa bagi siswa yang mempunyai minat belajar Fiqih rendah, terkait dengan sifat subjek siswa dan pendekatan interaksi pembelajaran kompetitif itu sendiri..

\section{PENUTUP}

Kesimpulan

Berdasarkan hasil pengujian Hipotesis berikut pembahasannya, dapat disimpulkan sebagai berikut:

1. Secara keseluruhan, hasil belajar Fiqih siswa yang diberi perlakuan Pembelajaran kooperatif lebih tinggi dari hasil belajar Fiqih siswa yang diberi pembelajaran kompetitif.

2. Untuk siswa yang memiliki minat belajar tinggi, hasil belajar Fiqih bagi siswa yang diberi perlakuan Pembelajaran kooperatif lebih tinggi dari siswa yang diberi pembelajaran kompetitif.

3. Untuk siswa yang memiliki minat belajar rendah, hasil belajar Fiqih bagi siswa 
yang diberi pembelajaran kompetitif, lebih tinggi dari yang diberi perlakuan Pembelajaran kooperatif.

4. Terdapat pengaruh interaksi antara Pembelajaran kooperatif dan kompetitif learning dengan minat belajar (tinggi dan rendah) terhadap hasil belajar Fiqih siswa.

Berdasarkan temuan-temuan maka dapat disimpulkan bahwa variasi hasil belajar Fiqih siswa MTS Kelas VIII dipengaruhi oleh model pembelajaran Pembelajaran kooperatif dengan memperhatikan minat belajar mereka.

Saran

1. Model pembelajaran kooperatif ini dapat digunakan sebagai salah satu alternatif dalam pembelajaran Fiqih, karena dengan metode ini pencapaian keberhasilan Fiqih secara keseluruhan terbukti lebih tinggi dari pembelajaran kompetitif. Dengan kata lain pembelajaran kooperatif dapat dijadikan sebagai pedoman pembelajaran oleh guru Fiqih.

2. Minat belajar sebagai salah satu faktor yang turut memberikan dukungan dalam proses pembelajaran Fiqih siswa, sebaiknya sudah harus dikenali guru Fiqih di MTS. Minat belajar dapat membantu guru Fiqih di MTS untuk menyesuaikan pembelajaran Fiqih agar terbentuk lapisan masyarakat yang bermoral.

3. Hasil penelitian ini diharapkan dapat dijadikan sebagai bahan masukan dalam mengembangkan teori melalui penelitian lanjut pada bidang yang sama.

4. Perlu penelitian lebih lanjut yang berkaitan dengan pengaruh pembelajaran kooperatif terhadap hasil belajar khususnya hasil belajar Fiqih pada tempat yang memiliki karakteristik yang sama.

5. Bagi siswa yang memiliki minat belajar indpenden perlu pertimbangan bagi guru untuk memberikan model pembelajaran kompetitif.

\section{SUMBER BACAAN}

Bloom, Benjamin S (1981): Taxonomy of Educational Objective (ed). Handbook 1: Cognitive Domain. New York: Longman Inc.

Ronald, Brant (1997): Cooperative Learning. New Yersey: Houghton Miffin.Co.

Johnson, David W and Roger T. Johnson (1996) Cooperation and the Use of technology, New York: McMillian Library Reference USA,

Dewi, Sofia (2008): Pengaruh Strategi Pembelajaran Kolaboratif dengan Strategi PembelajaranKompetitifdankemampuanawal terhadap Hasil Belajar Matematika. Jakarta: Program Pasca Sarjana UNJ

Direktorat Kelembagaan Agama Islam Depatemen Agama RI (2004): Standar Kompetensi Madrasah Tsanawiyah. Jakarta: Depatemen Agama Rl,

Faisal, Sanapiah (1989): Format -format Penelitian Sosial. Dasar-dasar dan Aplikasi. Jakarta; CV. Rajawali.

Hamalik, Oemar (2004): Perencanaan Berdasarkan Pendekatan Sistem. Jakarta: Bumi Aksara.

http://hanga.up.ac.za/catts/learner/2000/scheepers_md/projects/loo/ theory/individ

Journal. 1998, http.www.enc.org/reform/ journals/ENC2280/htm

Lester D. Crow \& Alice Crow (1973): Educational Psychology. New York: American Book Co.,

Lie, Anita Cooperattive Learning: Mempraktikkan Cooperative Learning di RuangRuang Kelas Terjemahan (Jakarta: Grasindo )

Program Pascasarjana UHAMKA (2008), Pedoman Tesis dan Disertasi. UHAMKA PRESS

Robert M. Gagne \& Leslie J. Briggs (1979): Principles of Instructional Design, New York: Holt Rinehart and Winston 
Robert. E Slavin (1995): Cooperative Learning. Theory, Research, and Practice. Massachusets: Allyn \& Bacon.

Soemanto, Wasty (1998): Psikologi Pendidikan. Jakarta: Rineka Cipta,

Syamsuddin AR dan Vismaia S. Damaianti (2007): Metode Penelitian Pendidikan Bahasa. Bandung: Remaja Rosdakarya.
Thomas L. Good, and Jere E. Brophy (1990): Educational Psychology, A Realistic Approach. New York: Longman

Undang-Undang Republik Indonesia Nomor 20 Th. 2003, Jakarta: CV. Medya Duta 